\title{
REVIEW
}

\section{Phylogeny and evolution of chemical communication: an endocrine approach}

\section{A M Stoka}

Centro Regional de Investigaciones Científicas y Tecnológicas (CRICYT) Mendoza, Argentina

Delegación Sanitaria Federal, Ministerio de Salud y Acción Social, Mendoza, Argentina

Facultad de Ciencias Médicas, Universidad Nacional de Cuyo, Mendoza, Argentina

(Requests for offprints should be addressed to A M Stoka at J B Justo 370, piso 2, dto 22, 5500 Mendoza, Argentina)

\begin{abstract}
The present review assesses the phylogenetic history of information molecules (bioregulators pheromones, hormones, neuroactive compounds), receptors, transducers, second messengers) in uni- and multicellular organisms.

Transitional stages between contemporary endocrine secretions including hormones and neuroactive materials, and primogenial exocrine
\end{abstract}

compounds (pheromones) are proposed. Several hypotheses have been developed to explain the origin and evolution of bioregulator/receptor units.

Finally, how these primordial information molecules have either been co-opted or have changed their function during the course of biological evolution is analysed.

Fournal of Molecular Endocrinology (1999) 22, 207-225

\section{INTRODUCTION}

Successful biological evolution may be considered to have, in large part, resulted from chemical communication using messengers such as food signals and toxins; these may be regarded as the primary conduits for information in the biosphere. The emergence of multicellular organisms, such as vertebrates, necessitates the differentiation and specialization of multiple chemical signalling systems organized in a network to carry the diffusible signal from one cell to the other (Fig. 1) either between or within several compartments.

The existence of an endocrine system as such conceptually demands multicellularity, but the actions of bioregulators are not restricted to the classical concept of hormones as endocrine signals. The tenor that 'compounds secreted by endocrine structures (glandular or nervous cells) and transported to other parts of the body by way of the blood-stream (or other fluids), where they evoke physiological responses' no longer applies.

Indeed, many bioregulators such as pheromones, paracrine substances, and growth factors do not originate from defined glandular or nervous structures and are delivered to their sites of action in many ways (Fig. 1). Chemical communication is central to evolutionary history; many types of information molecules including bioregulators, receptors, transducers, effectors and second messengers are almost universally present. Uni- and multicellular organisms are likely to share biosynthetic and functional mechanisms in terms of their chemical communication.

The use of phylogenetic perspectives to reconstruct evolutionary history has become increasingly important and provides solutions to basic questions in the area of chemical communications. Bioregulators, secretory cells and target tissues have left no palaeontological record, but the evolution of chemical communication can be extrapolated from comparative analyses of extant organisms.

In addition, the living record is of course far richer and more extensive than the fossil one, because cells today retain important information about their past in terms of amino acid sequences of their proteins and in the composition of nucleic acids (RNA, DNA). 


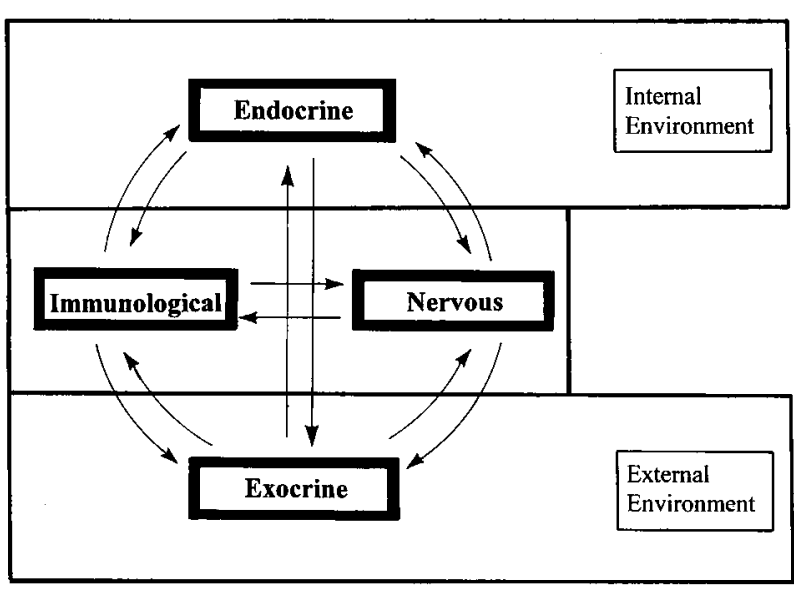

FIGURE 1. Interactions among chemical signalling systems and their respective environments. Bioregulators travelling through internal (blood stream, haemolymph) or external (water, air) environments are called hormones (or neurotransmitters, etc.) and pheromones respectively. In some cases, a bioregulator acts simultaneously as hormone and pheromone as occurs in the interaction between host and parasite (see Interspecific Communication).

Thus, a phylogenetic analysis of the distribution, biological functions and mechanisms of action of informational molecules is a logical way to gain insight into evolutionary trends and history.

\section{INTRASPECIFIC COMMUNICATION}

The ubiquity of bioregulators throughout the biosphere suggests that these compounds predate truly hormonal roles, and chemical communication took place among unicellular organisms prior to the emergence of Metazoa.

Two primary secretory systems may be recognised depending on the routes they take following release. One type involves the synthesis and release of materials which have actions within the organism itself (contemporary endocrine system). The second type of secretion includes pheromonal systems in which the secretion leaves the organism, either as liquid or gas, to affect the function of a second organism (primordial exocrine system).

The variety and ubiquity of pheromonal molecules (cyclic nucleotide, amino acids, small peptides, large proteins, alkanes, ketones, terpenoids, steroids; Table 1, Fig. 2) renders it likely that such substances in unicellular organisms evolved into the hormones of multicellular organisms.
The earliest phylogenetic example of intraspecific communication at cellular organization level is the aggregation process (Bonner 1971, Schapp 1984) of unicellular organisms of the same species in which there is directed migration towards a region of higher concentration of pheromone (paracrine signal) (Table 1).

In addition, some pheromones are produced in the same cell in which they exert their effects, referred as to an autocrine signal; this type of self-stimulation is seen in the protozoan Euplotes raikovi (Vallesi et al. 1995). There are two kinds of pheromone-receptor interactions in this species: (i) autocrine pheromone receptors (cell division) and (ii) paracrine pheromone receptors (mating behaviour). In the first type of interaction the pheromones cause mitogenic proliferation of the same cells from which they were secreted. In the second type of interaction these cells interrupt their vegetative cycle and are triggered towards mating behaviour when non-self co-specific pheromones act on paracrine pheromone receptors.

There are broad paradigms for the evolution of the chemical communication involved in these biological responses: (i) the same information molecule can develop more than one physiological function; (ii) the autocrine and paracrine functions appeared prior to the origin of endocrine function; (iii) reciprocal interaction between members of the same species began in an asocial environment (without colonies and without co-operative interactions) preceding the development of multicellular organisms.

Chemical communication ranges from prokaryotes responding to a wide variety of environmental chemical signals to the complex endocrine regulatory processes in multicellular organisms. Certainly, the ubiquity of the vertebrate information molecules (Table 2) is a product of natural selection-adaptation events.

It is, however, important to distinguish between characteristics selected for one function (adaptation process) from those originally selected for one function but subsequently employed by chance in an extension of the initial function (exaptation process) (Gould \& Vrba 1982).

A particularly good example of this is seen in invertebrate and vertebrate metamorphoses, spectacular biological processes regulated by a variety of hormones (Bentley 1976, Stoka 1987). In this process, juvenile hormone (sesquiterpenoid, Insecta) and prolactin (polypeptide, Amphibia) act as juvenile agents, although they are also involved in reproductive functions (Bern \& Nicoll 1969, Highnam \& Hill 1977). The ancestral insects and amphibians were essentially aquatic, metamorphosis 


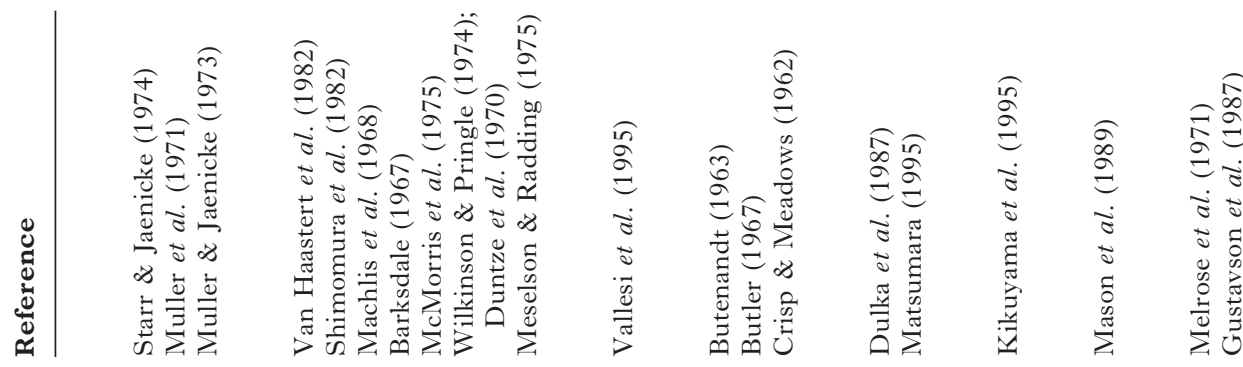
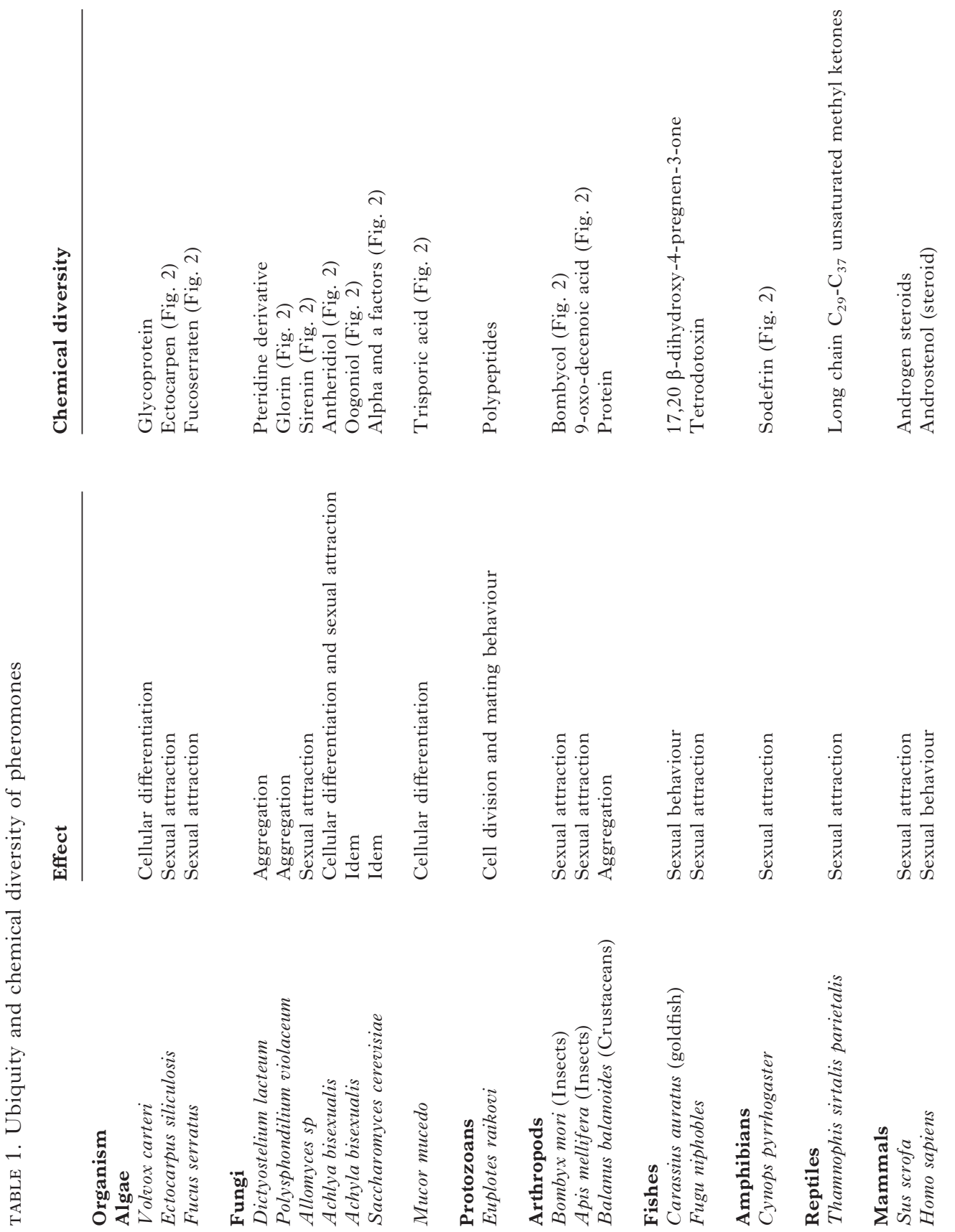

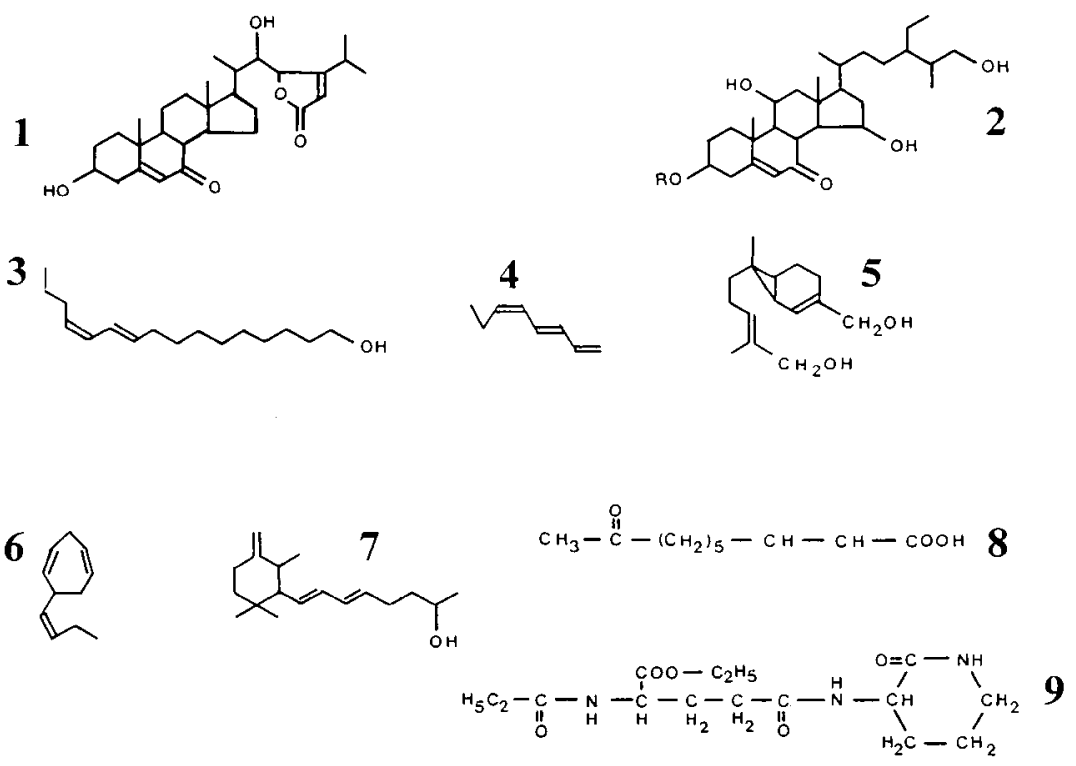

10

Ser-Ile-Pro-Ser-Lys-ASP - Ala - LeU - LeU - Lys - NH

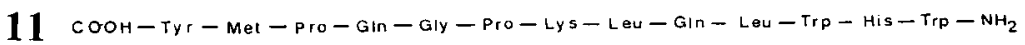

$12 \mathrm{COOH}-P_{r o}-A s x-A l a-T_{r p}-P_{h}-V_{a l}-$ Gly - Lys $-I l e-I l e-T_{y r}-\mathrm{NH}_{2}$

FIGURE 2. Lipid-type and peptide-type structures of exocrine bioregulators (pheromones). 1, Antheridiol; 2, oogoniol; 3, bombycol; 4, fucoserraten; 5, sirenin; 6, ectocarpen; 7, trisporic acid; 8, 9-oxo-decenoic acid; 9, glorin; 10, sodefrin; 11, alpha-factor; 12, a-factor. Alpha-factor from Saccharomyces cerevisiae has structural homology and functional analogy with a vertebrate-type hormone (see Table 2).

being an adaptation process to permit aquatic and terrestrial life styles ('Toms 1984).

\section{Can the primordial functions of juvenile hormone and prolactin be identified?}

Insect metamorphosis is linked to sexual maturation and the primordial function of juvenile hormone was probably to regulate the reproductive cycle of the ametabolous ancestors (Apterygota) of winged insects. The most primitive contemporary insects, Apterygota, display virtually no metamorphosis and juvenile hormone acts only on reproductive tissues.

In contrast, prolactin may be seen as an osmoregulatory hormone in fish. Thus, the morphogenetic and regulatory effects of the juvenile hormone and the later physiological attributes of prolactin (milk secretion in mammals, crop-milk production in birds, water-drive behaviour in amphibians) are secondarily evolved, when juvenile hormone and prolactin were used by other tissues or species.

The acquisition of new advantageous functions by a determined bioregulator might be an opportun- istic process in which novel structures (receptors, transducers, effectors) and new domains of an old bioregulator developed new physiological functions in other tissues and/or species. This kind of evolutionary opportunism characterizes the phylogeny of chemical communication (exaptation process).

\section{INTERSPECIFIC COMMUNICATION}

Evolutionary opportunism is commonly seen in the interactions between hosts and parasites. Examination of these relationships reveals that in some cases there are indeed effects on the hormonal regulation of development. Several studies (Table 3) described cellular receptors of host hormones in parasites which can respond differently with respect to their hosts (heterotrophic effects).

With respect to the effect of host hormones on parasites (Table 3) there is evidence for the hypothesis that some bioregulators originally served 
as a defence molecule: (i) vertebrate-type steroid hormones are present in insects (Schildknecht et al. 1966, 1967) and steroid derivatives occur in coelenterates (Sturaro et al. 1982), and they act as defence mediators towards other species; (ii) sterols and steroids have antimicrobial effects (Buetow \& Levedahl 1964); (iii) host hormones can inhibit the growth of parasites (Loose et al. 1983, Schar et al. 1986, Stoka 1996); (iv) several phytocompounds disrupt insect development (Stoka et al. 1987a).

Examples of transitional stages in the evolution of defensive and hormonal functions may also be noted: (i) a neurotoxin is a male attractant pheromone in vertebrates (Matsumara 1995); (ii) enterotoxins induce steroidogenesis in adrenocortical cells (Donta \& Moon 1974); (iii) cholera toxin $\beta$-chain and vertebrate glycoprotein hormones (thyroid-stimulating hormone, luteinizing hormone, follicle-stimulating hormone) share structural similarities (Kurosky et al. 1977); (iv) the finding of chemical signalling systems in plants that play dual roles as growth regulators and as a defence mechanism against pathogens (Chang et al. 1993, Chen et al. 1993).

Heterotrophic effects can also be viewed as (i) an adaptive strategy of parasites that renders it advantageous to co-ordinate their physiological functions with the physiological stage of their host. For example, 20-OH-ecdysone acts as a moulting hormone in insects, but can also stimulate growth and sexual differentiation in the protozoan parasite Trichonympha sp. (Cleveland 1959); (ii) a mechanism for pre-existing hormones to evolve in other target tissues or species (exaptation process). In unicellular organisms vertebrate-type bioregulators affect their growth (Table 3), while in multicellular organisms they are involved in sexual activity and metamorphosis (Baulieu et al. 1978, Geuns 1978, Stoka 1987, Stoka et al. 1987b). It is likely that receptors originally triggered one physiological response after interacting with a specific bioregulator, but subsequent changes (e.g. coupling with different transducers and effectors) allowed the development of additional physiological responses. This adaptive acquisition, with an old bioregulator playing a new function, is perhaps the most important consequence of transitional stages of change.

\section{EVOLUTIONARY ASPECTS OF EXOCRINE AND ENDOCRINE SYSTEMS}

Transitional stages are, phylogenetically, key points during the divergent evolution of uni- and multicellular organisms. In an evolutionary sense primitive pheromones are a transitional stage between the most primitive (food signals, toxins) and the most advanced (hormones, neuroactive compounds) chemical signals.

Current data are in agreement with the hypothesis that pheromones are ancestors of present-day hormones and that they arose very early during the evolutionary history as local cellular signals in unicellular organisms (primordial exocrine system).

Essentially, these bioregulators act as autocrine and paracrine factors (Vallesi et al. 1995). For example, cAMP regulates the metabolism of prokaryotes (autocrine action) (Mackman \& Sutherland 1965), and regulates many activities in unicellular eukaryotes (paracrine action) (Schapp 1984). Moreover, cAMP plays a dual role as intra- and intercellular messenger in Dictyostelium discoideum (Gerish 1987).

\section{What are the origins of this dual role of cAMP?}

If a bioregulator acts as inter- and intracellular messenger receptor transformations must be involved. For instance, the action of cAMP as second messenger suggests that an internalization process takes place, because in Escherichia coli cAMP is produced in the same cell in which it exerts its effects (autocrine action) and forms a complex with an extracellular specific protein, the cAMP-receptor protein (CRP) (Mackman \& Sutherland 1965). This protein is homologous to protein kinases, which are intracellular cAMP receptors in unicellular eukaryotes (Weber et al. 1982, Saxe et al. 1991).

It is obvious that with the development of multicellularity, cAMP cannot act as a cell-to-cell messenger because of its intrinsic chemical instability, and can only carry information as an intracellular second messenger by means of cytosolic cAMP-dependent protein kinases (Weber et al. 1982).

The presence of membrane and cytosolic cAMP receptors suggests the development of transitional stages during evolution. Clearly, each form of cAMP/cAMP receptor unit is linked to a determined facet within the evolutionary triptych of bioregulator-receptor interaction including: (i) autocrine (membrane form of cAMP receptor, cAMP=first messenger); (ii) paracrine (membrane and cytosolic forms of cAMP receptor, $\mathrm{cAMP}=$ first and second messenger); (iii) endocrine (cytosolic form of cAMP receptor, $\mathrm{cAMP}=$ second messenger).

The transitional taxonomic level on the cAMP receptor evolution may be represented today by Dictyostelium discoideum, an intermediate stage displaying: (i) a level of organization that is 
TABLE 2. Ubiquity of information molecules with structural homology and/or functional analogy to those of vertebrates

\section{Organism}

\section{Archaebacteria}

Halobacterium halobium

Binding protein for:

\section{Eubacteria}

Escherichia coli

\section{Clostridium perfringens}

Progenitor cryptocides

Yersinia enterocolitica

Pseudomonas testosteroni

Pseudomonas maltophilia

\section{Fungi}

Dictyostelium discoideum

Saccharomyces cerevisiae

Neurospora crassa

Trichophyton mentagrophytes

Paracoccidioides brasiliensis

Candida albicans

\section{Protozoa}

Trypanosoma cruzi

Tetrahymena pyriformis

G-protein

$-$

-

Thyrotrophin

Testosterone

Human choriogonadotrophin

-
-
-
-
-
$4 \cdot 2 \times 10^{-8} \mathrm{M}$
$6 \cdot 7 \times 10^{-9} \mathrm{M}$
$2 \cdot 3 \times 10^{-9} \mathrm{M}$

Insulin

Somatostatin

Thyrotrophin

Human choriogonadotrophin

-

17ß-Oestradiol

$\mathrm{GnRH}$

Progesterone

$17 \beta$-Oestradiol

Corticosterone

-

$3.0 \times 10^{-9} \mathrm{M}$

$1.0 \times 10^{-6} \mathrm{M}$

-

17ß-Oestradio

Alpha factor homologous to $\mathrm{GnRH}$

Insulin

$6.8 \times 10^{-8} \mathrm{M} \quad-$

$1.5 \times 10^{-8} \mathrm{M} \quad-$

$7 \cdot 2 \times 10^{-9} \mathrm{M}$

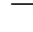

-

-

-

Relaxin

Insulin

Adrenocorticotrophic hormone,

B-endorphin, somatostatin

Adrenaline, noradrenaline

Dopamine, noradrenaline

Adrenaline, noradrenaline, dopamine, serotonine

-

$59 \mathrm{kDa}$

Schimz et al. (1989)

Ahnn et al. (1986)

Le Roith et al. (1981a)

Le Roith et al. (1985a)

Macchia et al. (1967)

Maruo et al. (1979)

Weiss et al. (1983)

Watanabe et al. (1973a)

Richert \& Ryan (1977)

$42 \mathrm{kDa} \quad$ Leichtling et al. (1981)

$54 \mathrm{kDa} \quad$ Brock et al. (1985)

- Feldman et al. (1982, 1984)

- Loumaye et al. (1982)

- $\quad$ Le Roith et al. (1980)

Schar et al. (1986)

Loose et al. (1983)

Loose \& Feldman (1982)

Eisenschlos et al. (1986)

Schwabe et al. (1983)

Le Roith et al. (1980)

Le Roith et al. (1983)

Janakidevi et al. (1966)

Welsh \& King (1970)

Planarians

Annelids

Glycera convoluta

Insulin

Anodonta cignea

Mytilus edulis

Lymnaea stagnalis
-
Testosterone, $17 \beta$-oestradiol Somatostatin 

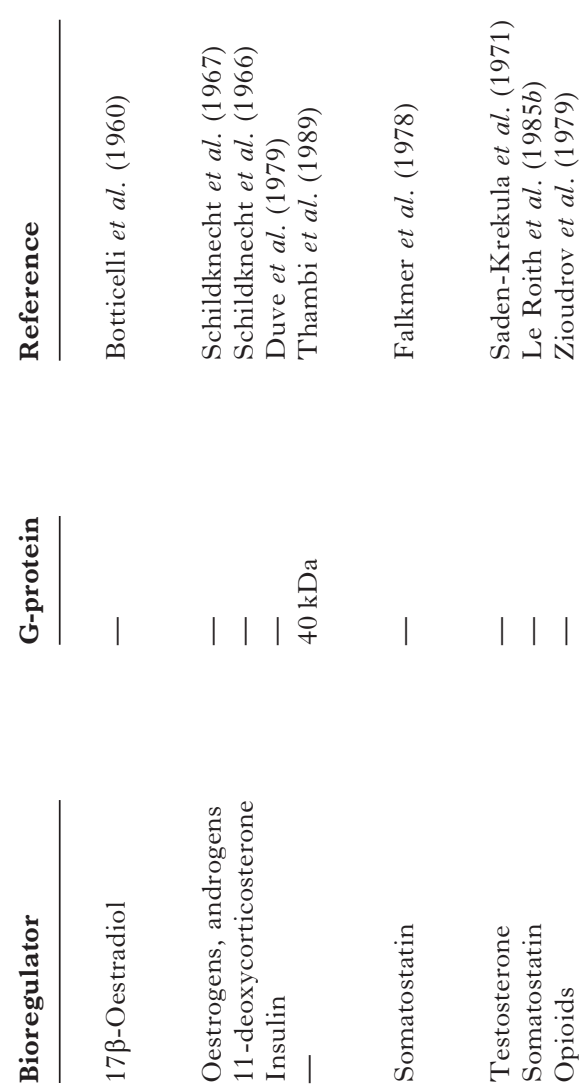

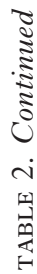
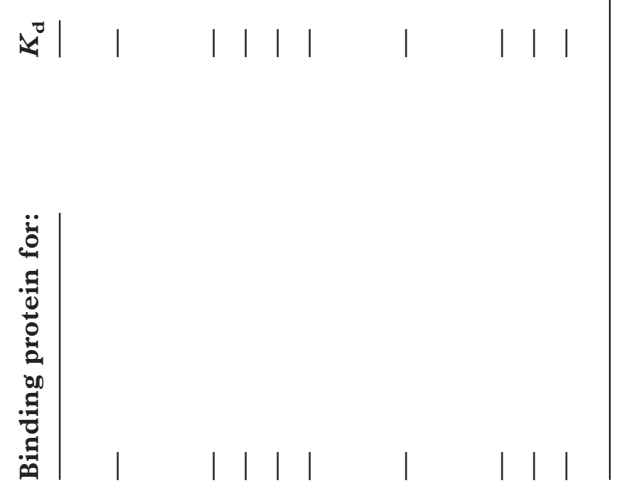

transitional between prokaryotic and multicellular organisms; (ii) D. discoideum has both membrane and cytosolic forms of cAMP receptors; (iii) in this species cAMP acts as a paracrine bioregulator (first messenger) and intracellular regulatory molecule (second messenger) (Table 4).

It seems likely that in the development of transitional stages such as $D$. discoideum, the earliest membrane receptors were the predecessors of cytosolic receptors. There are other examples of transitional stages; for example, progesterone, testosterone and gonadotrophins can act through both membrane and cytosolic receptors (Baulieu et al. 1978, Rao \& Chegini 1983, Diez et al. 1984).

Briefly, contemporary endocrine bioregulators (hormones, neuroactive materials) were probably, in the past, exocrine information molecules (food signals, pheromones), and their contemporary clearly defined endocrine functions (sexual reproduction, developmental processes) are more a product of target tissue specialization (e.g. transduction mechanisms) than a consequence of changes in the structure of the bioregulators themselves.

These views are supported by several observations: (i) the most effective signals for the chemotactic response in E. coli (maltose, glucose, serine, aspartate) are used as nutritive molecules (Adler 1969) in contrast to more specialized bioregulators (neuroactive compounds, hormones); (ii) the receptors or binding proteins in unicellular organisms display clear threshold values for chemotaxis towards a particular bioregulator (Adler 1975), which resemble the dissociation constant $\left(K_{\mathrm{d}}\right)$ of vertebrate-type bioregulators (Table 2). For example the threshold value of reduced glutathione (GSH), a feeding response activator (Lenhoff 1968, Colasanti et al. 1995), in Hydra littoralis, a member of one of the most ancient phyla among multicellular organisms, the Coelenterates, is $10^{-9} \mathrm{M}$.

GSH has, phylogenetically, the characteristics of a transitional stage among food signals and contemporary bioregulators (hormones, pheromones) because: (i) it plays a dual role acting in Hydra both as a chemical signal for detection of food sources, and as a neuromodulator of behavioural feeding response; (ii) like contemporary bioregulators, GSH is not used as a nutritive molecule.

In addition, primitive peptides and ancestral lipid molecules (sterols, steroids) were probably all growth promoting factors as a consequence of their intrinsic nutritional value. For example, Pseudomonas testosteroni is a prokaryote capable of utilizing steroids as their only carbon source (Watanabe et al. 1973a,b).

It is thus important to note a plausible relationship among some enzymes involved in the 

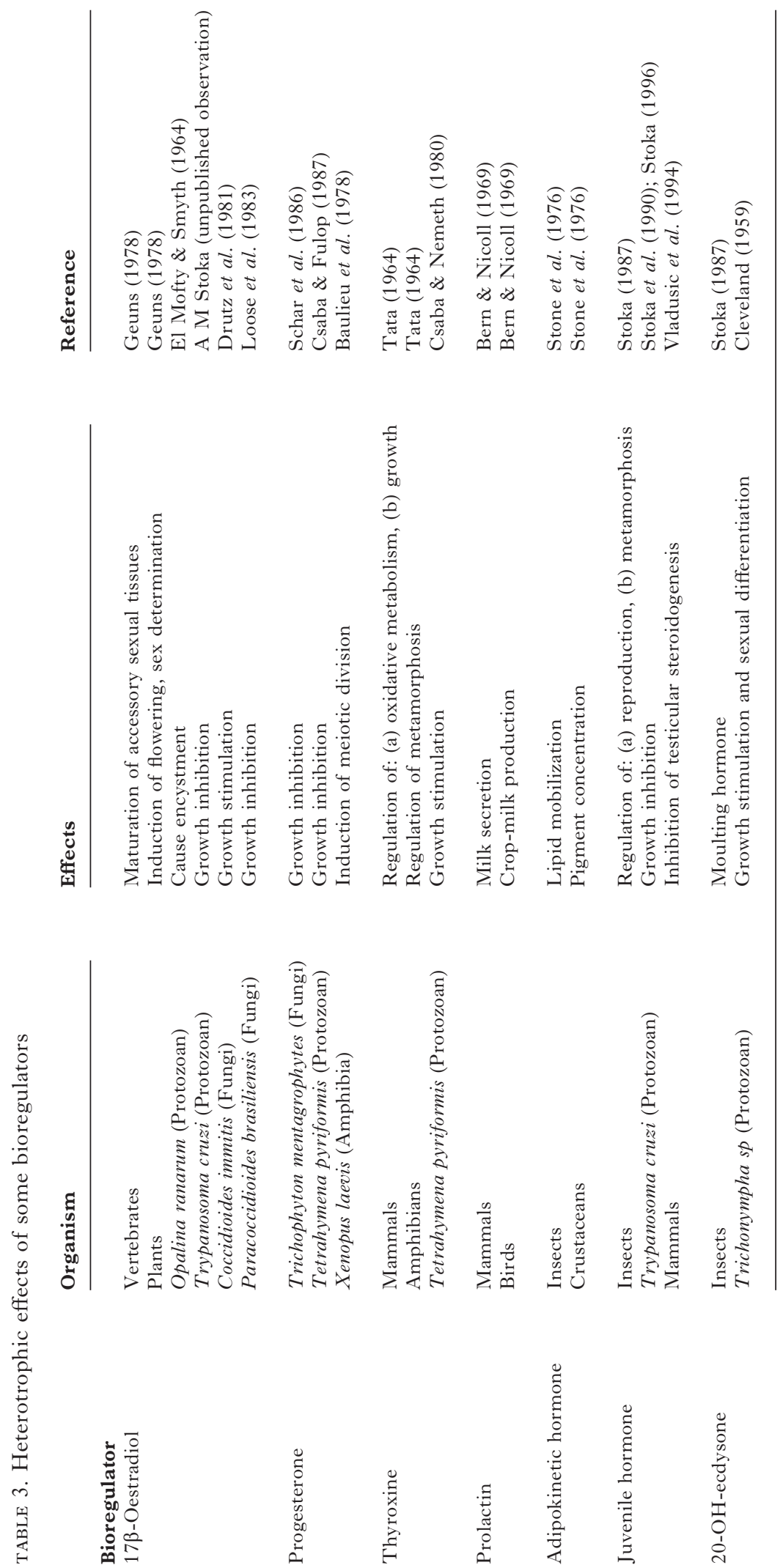
TABLE 4. Evolutionary transition of cAMP-receptors: from membrane to cytosolic environment

\begin{tabular}{|c|c|c|c|c|}
\hline & Organism & $\begin{array}{l}\text { Type of c-AMP } \\
\text { receptor }\end{array}$ & $\begin{array}{l}\text { c-AMP } \\
\text { function }\end{array}$ & $\begin{array}{l}\text { Interaction } \\
\text { c-AMP/c-AMP } \\
\text { receptor }\end{array}$ \\
\hline \multicolumn{5}{|l|}{$\begin{array}{l}\text { Organization } \\
\text { level }\end{array}$} \\
\hline *Prokaryote & Escherichia coli & Membrane form & First messenger & Autocrine \\
\hline$\nmid$ Eukaryote unicellular & Dictyostelium discoideum & Membrane and cytosolic forms & First and second messenger & Paracrine \\
\hline$\ddagger$ Eukaryote multicellular & Vertebrates and invertebrates & Cytosolic form & Second messenger & Endocrine \\
\hline
\end{tabular}

*Mackman \& Sutherland (1965); †Gerish (1987); Saxe et al. (1991); łWeber et al. (1982).

metabolism of bioregulators, and the origin of receptors. An interesting point of view is that binding and catalytic activities of some cell surface receptors arose from primitive enzymes. This hypothesis is supported by the presence of some transitional stages among enzymes and receptors: (i) the transport of testosterone in membrane vesicles of $P$. testosteroni is coupled to membrane bound $3 \beta$ and $17 \beta$-hydroxysteroid dehydrogenases (Watanabe \& Po 1976); (ii) a membrane form of guanylate cyclase in mammals acts as a receptor for atrial natriureic peptide (Chinkers et al. 1989); and (iii) the cytosolic receptor for salicyclic acid in plants has catalase activity (Chen et al. 1993).

Furthermore, some point mutations in the binding site of an enzyme enhanced its substrate binding capacity although they produced a catalytically nonproductive species (Craik et al. 1985).

The catalytic and binding capacities of prokaryotes were probably employed in a different fashion to their contemporary hormonal ones in multicellular organisms and represented a vestige of Precambrian times (exaptation process). Some advantageous changes in the structure of prokaryotic enzymes involved in the metabolism of nutritive substrates (e.g. $3 \beta$ - and $17 \beta-$ hydroxysteroid dehydrogenases of $P$. testosteroni) may have 'filtered' through the natural selection process, and evolved into other functions such as autocrine, paracrine and/or endocrine signal receptors to facilitate regulation of intracellular processes. In this evolutionary scenario a different type of regulation may be considered. A bioregulator can be produced and act within the same cell (intracrine regulation) (O'Malley 1989). It is known that certain unicellular organisms biosynthesize steroid hormones and contain intracellular steroid receptors. Examples include Saccharomyces cerevisiae and Candida albicans (Loose et al. 1981, Loose \& Feldman 1982, Feldman et al. 1982, 1984).

If the first unicellular organisms possessed few multifunctional molecules, probably nutritional compounds would serve both as metabolic and regulatory elements. It is possible then, that intracrine regulation could be a transitional stage between regulation through metabolic substrates (nutritive line) and hormonal modulation (regulatory line).

Primitive members of the contemporary steroid receptors family were possibly membrane enzymes which bound environmental nutritional molecules (steroids, sterols), and their prime regulatory function was to control intracellular metabolism.

Such relationships between food signals and contemporary bioregulators do not preclude other parallel original functions of bioregulators in defence functions.

The primary role of ancestral bioregulators in unicellular organisms was a nutritional one, but the adaptive radiation among molecules produced compounds that were inhibitors (e.g. toxins) of enzymes involved in the growth of competitive species.

\section{PHYLOGENETIC ASPECTS OF BIOREGULATOR-RECEPTOR RELATIONSHIP}

Some ligand-binder relationships (substrate-enzyme, antigen-antibody, bioregulator-receptor) must be restricted to an interaction with specific and small regional domains within their structures, as exemplified by insulin and its receptor (Pullen et al. 1976).

The chemical structure of bioregulators has been well conserved through evolution and there are high degrees of homology within the system (Table 2). In addition, the divergent functions of bioregulators with a similar structure (e.g. progesterone/cortisol) pose a number of questions including the following.

\section{Have receptors evolved in a similar way? How similar and how different are receptors for different bioregulators?}

A case in point is that the amino acid sequences of nuclear thyroid hormone receptors display homology with a similar domain of several steroid 
hormone receptors (Weinberger et al. 1986). Thus, the relationship between steroid hormone receptors and thyroid hormone receptors suggests that all these receptor structures, including the $\mathrm{v}$-erb-A oncogene product of the avian erythroblastosis virus $(\mathrm{AEV})$, may be a superfamily of information molecules that have evolved in several divergent lines during their phylogeny. However, the existing homologies between the thyroid hormone receptors and steroid hormone receptors, vitamin $\mathrm{D}_{3}$, aldosterone, cortisol, testosterone, progesterone or oestradiol did not seemingly compete (Weinberger et al. 1986). Obviously, the secondary, tertiary and quaternary structures of the thyroid hormone receptor increase specificity for thyroid hormone.

\section{What is the origin of the bioregulator-receptor specificity?}

The origin of cell specificity for a determined bioregulator depends on the critical period of receptor maturation which determines its binding properties (Blazquez et al. 1976) and which may be influenced or altered by the action of a similar chemical structure (Csaba 1980).

On the other hand, the superfamily of steroid receptors, besides receptors binding thyroid hormones, retinoic acid or steroid hormones, contains orphan receptors for which no ligand is known (O’Malley 1989, Escriva et al. 1997). It seems likely that the number of ancestral steroid receptors (enzymes?) was expanded by the presence of immature receptors which adopted different binding site configurations with high specificity for particular ligands, as occurs with the evolution of antibody catalysis (Wedemayer et al. 1997).

Another aspect involved in the origin of bioregulator-receptor interaction is the structural similarity between secreted bioregulators and chemical components of cells. It has been suggested that pheromones and hormones evolved from membrane components (Kochert 1978, Pfeffer \& Ullrich 1985). Accordingly, there are two hypotheses to explain the origins of bioregulator-receptor units.

Hypothesis 1: polypeptide hormones are produced by proteolytic cleavage of membrane proteins of secondary lysosomes (Hales 1985)

The peptide hormone, epidermal growth factor (EGF), is cleaved from membrane protein (Kaback 1985). In addition, bioregulators and their receptors may evolve as a result of changes in the DNA by gene duplication and subsequent point mutational events. Some genes encoding receptor-bioregulator units began as single genes encoding single polypeptide molecules. Gene splitting and different gene expressions may have induced the synthesis of bioregulators and their receptors in different cell types (Niall 1982, Kaback 1985).

Hypothesis 2: the presence of a bioregulator is an essential condition for receptor formation (the theory of signal-imprinting, Csaba 1980)

During this process, there is likely to be initial contact between a chemical signal and a potential receptor region of the cell membrane, and induction of shape complementarity and hydrophobicity of the interacting surfaces may take place (Tainer et al. 1984).

However, it is not only the bioregulator-receptor unit which determines the quality of physiological responses under its control. Phylogenetically transducting systems involve trimeric G-proteins, identified in various prokaryotes (Ahnn et al. 1986, Schimz et al. 1989) and eukaryotes (Namba et al. 1983, Firtel et al. 1989, Whiteway et al. 1989).

In addition to the homologies among steroid receptors and thyroid hormone receptors (Weinberger et al. 1986), there is another type of homology - that of G-proteins. Key observations are: (i) the prostaglandin $\mathrm{E}$ receptor subtype EP3 and the tromboxane $\mathrm{A}_{2}$ receptor belong to the large superfamily of receptors coupled to G-proteins which consist of seven transmembrane domains (Namba et al. 1983) and are isoforms of rhodopsin (Franke et al. 1990) and dopamine receptors (Monsma et al. 1989); (ii) the sequence and size variation among receptor domains whereby receptors bind G-proteins (Monsma et al. 1989) suggest widespread diversity within the G-protein family. Thus, different physiological responses of receptor isoforms are structurally based (Fig. 3).

In addition, there is other evidence for conservation and functional versatility of information molecules: (i) the pheromone signalling pathway in $S$. cerevisiae is activated by an heterologous transducting system including the human $\beta$ adrenergic receptor and the rat Gs-protein (King et al. 1990); (ii) $S$. cerevisiae has a primitive steroid receptor system analogous to the mammalian oestradiol receptor unit (Feldman et al. 1982, 1984); (iii) a bioregulator can interact with autocrine and paracrine receptors to accrue more physiological functions (Mackman \& Sutherland 1965, Gerish 1987, Saxe et al. 1991, Vallesi et al. 1995); (iv) a receptor in combination with homologous bioregulators can regulate the same physiological response in a determined target tissue (Stone et al. 1976, Mordue \& Stone 1976, 1977); (v) a receptor can bind different bioregulators and elicit varying patterns of gene activation but with the same effects 


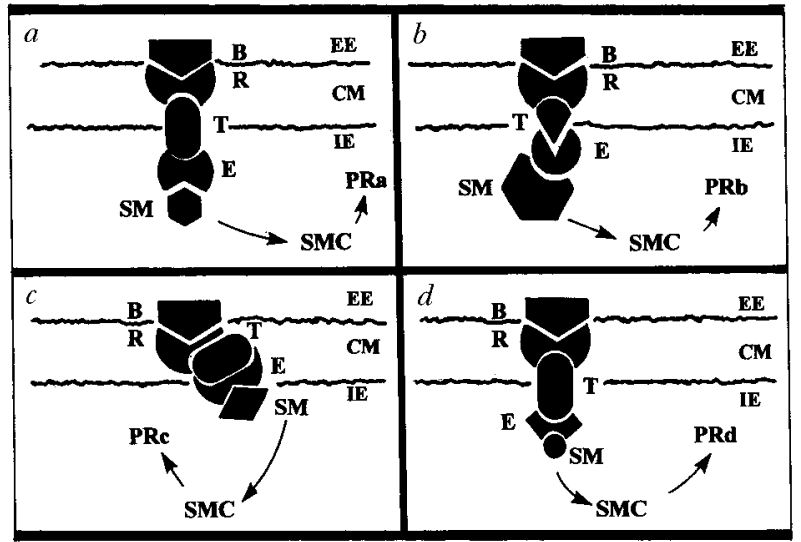

FIGURE 3. Different receptor isoforms can produce more than one physiological response. B, Bioregulator; $\mathrm{R}$, membrane receptor; $\mathrm{T}$, transducer (e.g. G-protein); E, effector (e.g. cyclases, phospholipases); SM, second messengers (e.g. cAMP); SMC, second messenger cascades (e.g. inositol triphosphate cascade); PR, physiological response; CM, cell membrane; EE, extracellular environment; IE, intracellular environment. The G-protein diversity probably results from multiple genes and/or alternative RNA splicing generating multiple isoforms from a single gene. Possible scenarios: ( $a$ and $b$ ) receptors are coupled to different transducers; ( $a$ and $c$ ) different domains of a determined receptor interact with the same transducer but with an analogous effector. This effector may react with the same or with a different second messenger; ( $a$ and $d$ ) receptor isoforms activate different effectors.

in a particular tissue (Yang et al. 1996, Paech et al. 1997).

\section{SOME HYPOTHESES TO EXPLAIN THE EVOLUTION OF INFORMATION MOLECULES}

A basic question is: were contemporary bioregulators (hormones, neuroactive compounds, growth factors, pheromones) primary chemical messengers such as food signals and defensive compounds?

Sterols have probably played an important function as growth bioregulators in the Precambrian period, $1000-3000 \times 10^{6}$ years ago. Some evidence supports this hypothesis: (i) cellular life may have been present about $3000 \times 10^{6}$ years ago as fermenting bacteria (Schwemmler 1984); (ii) sterol biosynthesis existed at a very early stage in some organisms such as the Cyanobacteria (blue-green algae, Nostoc, Spirulina) (Nes \& McKean 1977); (iii) some sterols participate in the activation of oocyte meiosis (Byskov et al. 1995) - a possible feature of ancestral bioregulators was the control of cell division; (iv) the presence of both binding and catalytic activities for vertebrate-type steroid hormones in aerobic bacteria (Watanabe et al. 1973a,b, Watanabe \& Po 1976).

Indeed there are important differences in structural conservation during the phylogeny of information molecules. Some bioregulators such as steroid and thyroid hormones are rigorously conserved because they result from enzymic cascades and require almost absolute substrate specificity. In contrast others (somatomammotrophins, pituitary glycoproteins, secretins) are direct gene products and will tolerate change providing the 'active' (receptor activating) portion of the peptide is not changed and variation can be tolerated (Henderson 1997).

In some cases, the structural evolution of information molecules produced a functional versatility of a hormone. For example, prolactin has acquired different functions among vertebrates: (i) osmoregulatory activity in fish; (ii) growthpromoting activity in tetrapods; (iii) metamorphosic actions in amphibians, and (iv) lactogenic activity for neonatal nutrition in mammals and birds (Bern \& Nicoll 1969).

Correlated with these physiological acquisitions, comparative studies on structural and functional bioregulator-receptor interactions reveal that both prolactin and prolactin receptors have undergone considerable changes (White \& Nicoll 1979), although there is no strict relationship between functional versatility and the number of chance substitutions in the structure of informational molecules.

A most striking example in this area is the structural change found in naturally occurring insulins among vertebrates. These insulins have different affinities for the insulin receptor in mammalian tissues (Muggeo et al. 1979) and they differ 50- to 100 -fold in their potency (Blundell et al. 1972).

At the level of specificities among ligands and binders, some bioregulator-receptor units seem to be in a transitional evolutionary stage according to their cross reactions, as occurs with arthropod neurohormones (Fig. 4, Table 5). In contrast, other bioregulator-receptor units such as the glucagon/ glucagon receptor unit (Blundell \& Humbel 1980) display maximum specificity. It is thus possible that different bioregulator-receptor units in a particular species evolved at different rates and times, as occurred with some morphological characteristics, a process termed mosaic evolution (De Beer 1954); there are several examples for different molecules (Wilson et al. 1977). From a functional point of view, the prolactin/prolactin receptor unit has evolved more rapidly than the insulin/insulin receptor unit 
AKH COOH - GLU - LEU - ASN - PHE - THR - PRO - ASN - TRP - GLY - THR - NH

CC-1 COOH - GLU - VAL - ASN - PHE - SER - PRO - ASN - TRP - $\mathrm{NH}_{2}$

RPCH COOH - GLU - LEU - ASN - PHE - SER - PRO - GLY -TRP - $\mathrm{NH}_{2}$

FIGURE 4. Structural homologies among arthropod neurohormones. The primary structures of red pigment concentrating hormone of prawn (RPCH, Crustacea, octapeptide), adipokinetic hormone of locust (AKH, Insecta, decapeptide) and periplanetin of cockroach (CC-1, Insecta, octapeptide) suggest that they evolved from a common precursor by gene duplication and subsequent point mutational events (*); then they diverged functionally. *AKH: Serine (SER) Threonine (THR) (amino acid position 5); CC-1: Leucine (LEU) - Valine (VAL) (amino acid position 2); RPCH: Asparagine(ASN) - Glycine (GLY) (amino acid position 7).

as judged by the number of known physiological functions acquired during vertebrate evolution.

In addition, the taxonomic distribution of insulin and prolactin differs (Fig. 5) and does not correlate with their functional versatility. In this regard, it may be that chemical communication arose many times during phylogeny and primordial information molecules, with functional and/or structural characteristics different to present-day bioregulatorreceptor units, may have appeared and disappeared as a result of changes in the expression of genetic information (point mutations, gene duplication, alternative splicing, transpositions, etc.). The very nature of the regulation of genetic transcription would indicate that the genome of contemporary biota must contain DNA regions with information for potential unexpressed bioregulator-receptor units, and therefore the specific group of presentday information molecules may be only one of several lineages.

TABLE 5. Effects of arthropods neurohormones
Indeed, these non-translated DNA regions (introns) are, in terms of genetic information, the remnant of phylogenetic history and the building blocks of current and future evolution.

This hypothesis is supported by ectopic endocrine activity of patients with neoplasia. It was observed that the occasional disruption of normal cell differentiation can produce nonendocrine tumours, capable of synthesizing a great amount of hormones (e.g. phaeochromocytoma) (Baylin \& Mendelsohn 1980). Such complicated and fascinating processes reflect a regression towards a primordial cellular stage; under such conditions it seems that there is a return to a cellular pluripotentiality for the biosynthesis of information molecules. Such potential information molecules may arise from 'hidden' sequences of DNA regions (introns) and developed unknown (extinct or new) bioregulator signalling mechanisms. Evolution in a sense can go into reverse to re-express earlier chemical communication systems.

It is also plausible that present-day chemical communication systems may be superior to primordial systems, but they may not necessarily always be so under some conditions.

\section{CONCLUSIONS}

The inherent similarity of mechanisms involved in bioregulator-receptor interactions reveals that glandular and nervous systems (endocrine systems) may have a common origin from a pheromonal system (primordial exocrine system) of unicellular organisms.

This hypothesis can explain many phenomena: (i) vertebrate-type hormones acting in unicellular organisms as pheromones that cause regulatory effects (Tables 2 and 3); (ii) the presence of vertebrate-type bioregulators (gastrin, somatostatin, prolactin) in classical exocrine fluids such as saliva, gastric juice and other humoral secretions (Le Roith

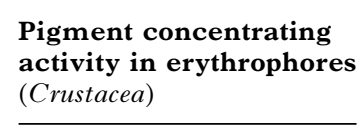

\section{Neurohormone}

†Adipokinetic hormone (AKH)

$\ddagger$ Periplanetin (CC-1)

$\S$ Red pigment concentrating hormone

$\frac{\text { Yes* }}{\text { Yes }}$

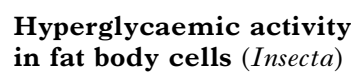

Adipokinetic activity in fat body cells (Insecta)

$\begin{array}{lc}\text { Yes* } & \text { Yes } \\ \text { Yes } & \text { Yes* } \\ - & \text { Yes* }\end{array}$

Cross-reactions (*) were observed among arthropod neurohormones. Probably binding and transduction activities of neurohormone receptors could have evolved independently. The evolution of arthropod neurohormones and their receptors seems to be an example in which specificity has not reached a maximum (transitional or immature stage).

†Mordue \& Stone (1976, 1977); Stone et al. (1976); łHanaoka \& Takahashi (1976); §Mordue \& Stone (1976, 1977); Ferlund (1974). 


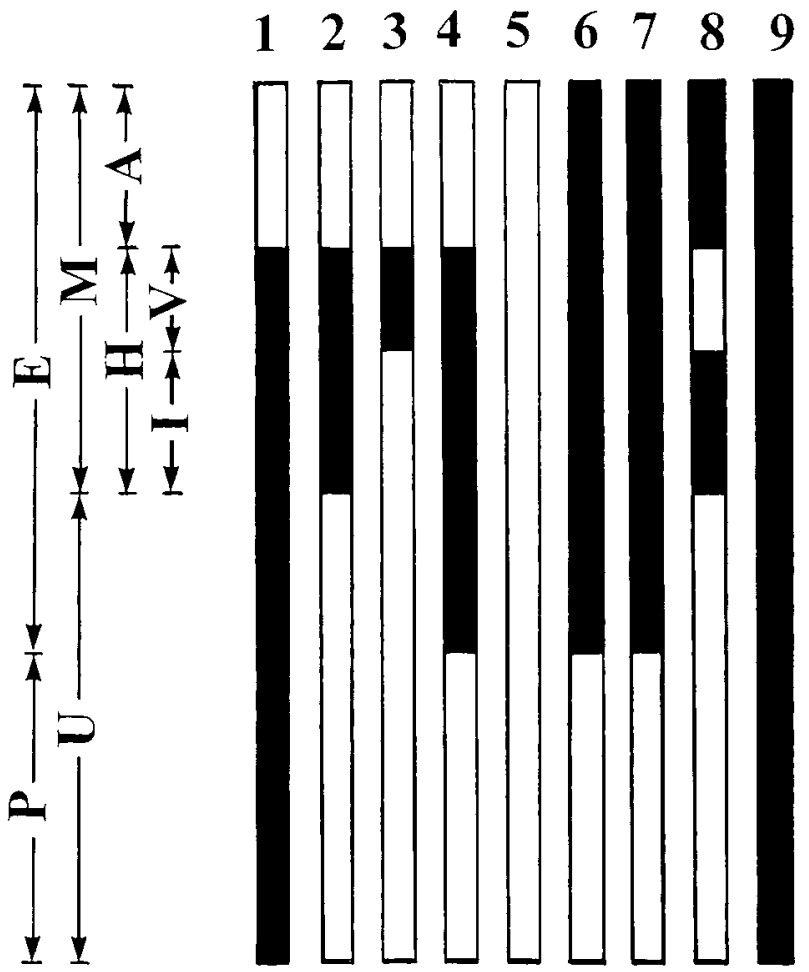

FIGURE 5. Conservation of some bioregulators during biological evolution. Some properties of bioregulatorreceptor units suggest that they may have evolved by selection of some other function, and then diverged functionally. Certainly, the conserved specific domains of bioregulator-receptor units and their presence in different taxonomic groups are consistent with a natural selection event to ensure survival and reproduction of new life forms (adaptation), but in certain cases (Riedel et al. 1986) their final physiological function is largely unknown (exaptation). D Present-day distribution of different bioregulators through different taxonomic levels. 1, Insulin; 2, glucagon; 3 , prolactin; 4, noradrenaline; 5 , potential but not expressed bioregulators; 6 , juvenile hormone and juvenile hormone analogues. Juvenile hormone activity has been found in protozoans (Fisher \& Sandborn 1962), arthropods (Judy et al. 1973), vertebrate tissues (Gilbert \& Schneiderman 1958, Williams et al. 1959) and plants (Slama \& Williams 1965, Bowers \& Nishida 1980)); 7, oestradiol; 8, 20-hydroxyecdysone; 9, somatostatin. $\square$ Extinct or unexpressed pathways of bioregulator biosynthesis in contemporary species. P, Prokaryotes; E, eukaryotes; $\mathrm{U}$, unicellular; M, multicellular; $\mathrm{H}$, heterotrophs; A, autotrophs; I, invertebrates; V, vertebrates.

et al. 1986); (iii) the ubiquity of insulin in extrapancreatic tissues of mammals (brain, liver, cultured lymphocytes and fibroblasts) (Rosenzweig et al. 1980), insects (Duve et al. 1979), annelids (Le Roith et al. 1981b) and unicellular organisms (Le
Roith et al. 1980, 1981b); (iv) the overlap of brain and gut bioregulators in mammals (Zimmerman 1979) and insects (Duve \& Thorpe 1981); (v) the biosynthesis of gastrointestinal hormones in neural, endocrine and paracrine cells (Grosman 1979); (vi) gonadal steroid hormones acting as defensive agents (Schildknecht et al. 1966, 1967, Loose et al. 1983, Schar et al. 1986); (vii) the presence of specific binding of insulin to the unicellular alga Acetabularia mediterranea (Legros et al. 1975); (viii) the ubiquitous distribution of thyrotrophin releasing hormone in the animal kingdom (Henderson 1997) and plants (Morley et al. 1980, Jackson 1981).

It is suggested that endocrine secretory mechanisms (glandular, nervous) have a common origin and are products of phylogenetic and evolutionary processes from unicellular organisms (primordial exocrine bioregulators) to multicellular organisms (contemporary exocrine and endocrine bioregulators).

On the other hand, receptor binding activities seem to have arisen as a result of modifications in the structure of enzymes. Within this hypothesis a divergent evolution is possible since enzyme binding activity need not always co-evolve with its intrinsic catalytic activity. Such an evolutionary mechanism enables receptors to be created without the development of additional binding sites (Stone et al. 1976, Shemshedini \& Wilson 1990, Lee et al. 1992).

It is not surprising that receptor evolution, as with other evolutionary characteristics, required millions of years during which some transitional stages (e.g. hormonal receptors with catalytic activity) predominated. Enzymes are thus the key to understanding the origin and evolution of both enzymes and receptor binding activities. Some basic questions are obviously raised: how similar are the binding regions of receptors and enzymes for a particular bioregulator? Is the origin of receptor and enzyme binding activities, for a particular bioregulator, a product of convergent or divergent evolutionary processes?

Although evidence is scanty, it is possible that by mutational and natural selection processes a bioregulator-receptor unit arose through initial divergent evolution followed by a convergent process. Convergent and divergent evolution have been noted in some eukaryotic phosphorylases (Hwang \& Fletterick 1986). Figure 6 illustrates possible sequences within the evolutionary history of bioregulator-receptor units.

The evolutionary development of chemical communication systems reflects parallel evolution of all information molecules (bioregulators, receptors, 


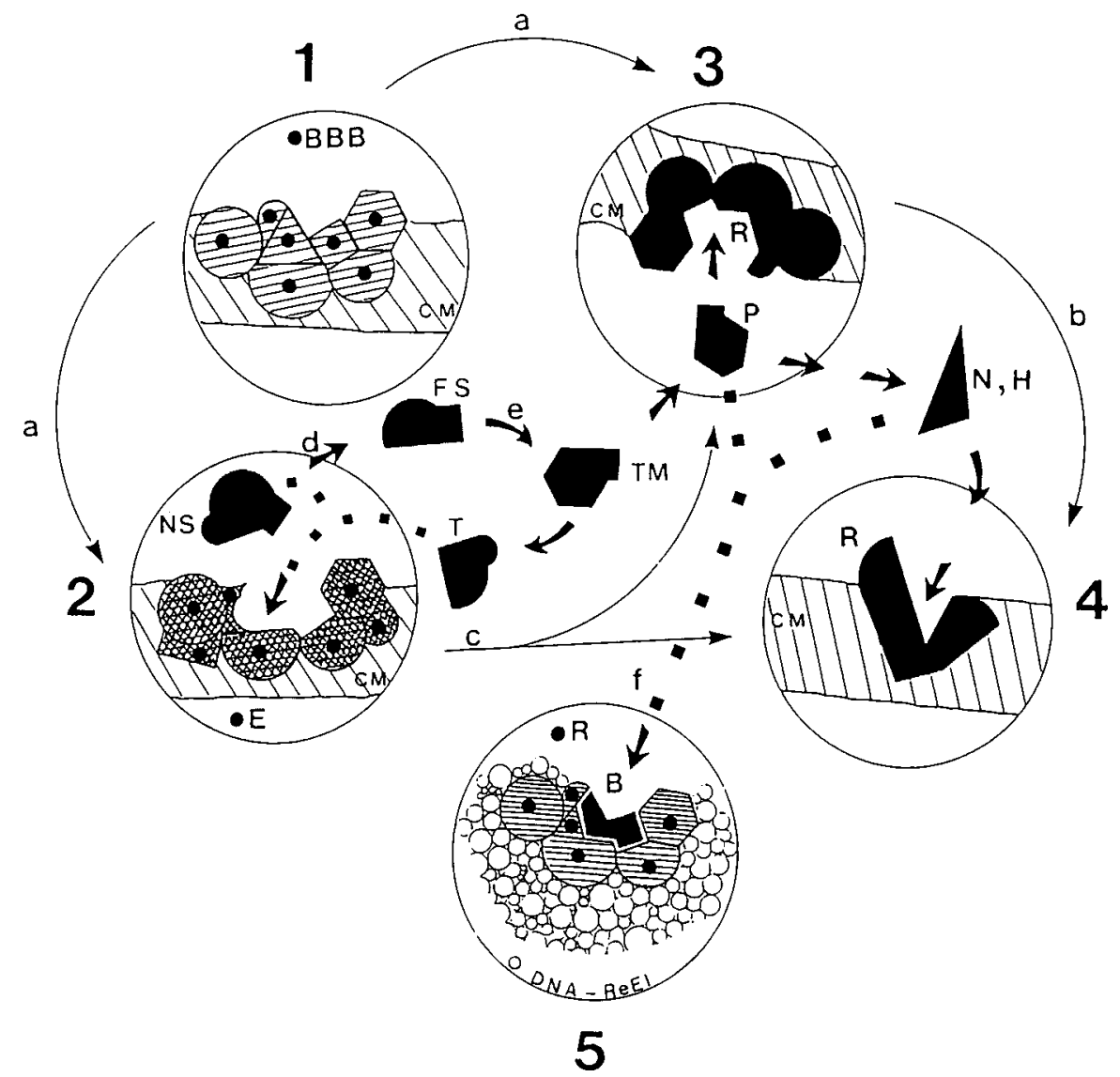

FIGURE 6. Hypothetical sequence of evolutionary transitions from a potential signal-receiver unit to bioregulator-receptor interaction. Evolutionary stages: 1, potential signal-receiver unit; 2 , substrate-enzyme interaction;

3 , pheromone-membrane receptor interaction; 4, neurotransmitter or hormone-receptor interaction; 5, bioregulator (pheromone, hormone, neurotransmitter)-nuclear receptor interaction. Initially, in this schematic representation, a potential signal-receiver unit (stage 1) may have evolved into two divergent models: (i) enzyme (membrane form)-substrate (nutritive line) (stage 2); (ii) membrane receptor-pheromone (regulatory line) (stage 3). After this divergent process, a convergent evolution is possible; for instance the receptor binding activities arose from enzymes involved in the metabolism of nutritive substrates as a result of: (i) point mutations in the binding site (transition c substrate specificity enhancement and catalytic activity diminution) (Craik et al. 1985); (ii) altered binding specificity may also influence interactions of some molecules (nutritive substrates, transition molecules) with membrane receptors which acquire a pheromonal status. On the other hand, these transition molecules may have evolved into toxins which may serve as enzyme inhibitors or enzyme activators. Transitions: a, origin of signal-receiver units through genetic or imprinting mechanisms; $\mathrm{b}$, origin of endocrine bioregulators (neurotransmitters, hormones, etc.) through the development of multicellularity; c, hormonal and pheromonal receptors arose from primitive enzymes; $d$, probable relationship between nutritive substrates and food signals; e, transition molecules (pheromone-like compounds) arose from advantageous changes in the structure of food signals; $f$, receptor internalization process: from membrane receptors to soluble intracellular receptors. BBB, biological building blocks; CM, cell membrane; DNA-ReEl, DNA-response element, $\mathrm{R}$, receptor; $\mathrm{H}$, hormone; $\mathrm{P}$, pheromone; NS, nutritive substrate; $\mathrm{E}$, enzyme; B, bioregulator (hormone, pheromone, etc.), TM, transition molecule; FS, food signal; $T$, toxin; N, neurotransmitter. 
transducers, enzymes, second messengers, second messenger cascades, etc.), which are sometimes co-ordinated and essential processes (adaptation) and are sometimes opportunistic and random events (exaptation).

Despite extensive accumulation of information over the last 20 years, many important gaps remain in our knowledge of phylogenetic relationships and genetic processes therein.

Virtually nothing is known about: (i) the effects of mutations in different kinds of genes (multiple genes, simple non-overlapping genes) that can be quite different according to their primary function, (ii) whether it is possible to describe the exact physico-chemical conditions and frequencies of new adaptations and exaptations.

Molecular endocrinology is now at a stage when some of these and other questions can be addressed. The author expects that this review will stimulate new routes of thinking in research teams that work in the area.

\section{ACKNOWLEDGEMENTS}

This work was carried out with financial assistance from Consejo Nacional de Investigaciones Cientificas y Tecnicas (CONICET), Argentina.

I thank Drs Luis Mayorga and Armando Parodi for useful comments on the manuscript. I would also like to express my thanks to Prof. I Henderson for his assistance in the revision of the manuscript.

\section{REFERENCES}

Adler JA 1969 Chemoreceptors in bacteria. Science $\mathbf{1 6 6}$ 1588-1597.

Adler JA 1975 Chemotaxis in bacteria. Annual Review of Biochemistry 44 341-356.

Ahnn J, March PE, Takiff HE \& Inouye M 1986 A GTPbinding protein of Escherichia coli has homology to yeast RAS proteins. Proceedings of the National Academy of Sciences of the USA 83 8849-8853.

Barksdale AW0 1967 The sexual hormones of the fungus Achlya. Annals of the New York Academy of Sciences 144 313-319.

Baulieu EE, Godeau F, Schorderet M \& Schorderet-Slatkine S 1978 Steroid-induced meiotic division in Xenopus laevis oocytes: surface and calcium. Nature 275 593-598.

Baylin SB \& Mendelsohn G 1980 Ectopic (inappropriate) hormone production by tumors: mechanisms involved and the biological and clinical implications. Endocrine Reviews 1 45-77.

Bentley PJ 1976 Comparative Vertebrate Endocrinology. New York: Cambridge University Press.

Bern HA \& Nicoll CS 1969 The taxonomic specificity of prolactins. Progress in Endocrinology Excerpta Medica, Amsterdam 433-439.

Blazquez E, Rubalcava B, Montesano R, Orci L \& Unger RH 1976 Development of insulin and glucagon binding and the adenylate cyclase response in liver membranes of the prenatal, postnatal and adult rat: evidence of glucagon 'resistance'. Endocrinology 98 1014-1023.

Blundell TL \& Humbel RE 1980 Hormone families: pancreatic hormones and homologous growth factors. Nature $\mathbf{2 8 7}$ 781-787.

Blundell TL, Dodson GG, Hodgkin DC \& Mercol DA 1972 Insulin: the structure in the crystals and its reflection in chemistry and biology. Advances in Protein Chemistry 26 279-402.

Bonner JT 1971 Aggregation and differentation in the cellular slime molds. Annual Review of Microbiology 25 75-92.

Botticelli CR, Hisaw FL \& Wotiz HH 1960 Estradiol-17 $\beta$ and progesterone in ovaries of starfish (Pisaster ochraceous). Proceedings of the Society of Experimental Biology and Medicine 103 875-877.

Bowers WS \& Nishida R 1980 Juvocimenes: potent juvenile hormone mimics from sweet basil. Science 209 1030-1032.

Brock D, Samily N, Fasano O, Fujiyama A, Tamanos F, Northup J \& Wigler M 1985 Differential activation of yeast adenylate cyclase by wild-type and mutant RAS proteins. Cell 41 763-769.

Buetow DE \& Levedahl BH 1964 Responses of microorganisms to sterols and steroids. Annual Review of Microbiology 18 167-194.

Butenandt A 1963 Bombycol, the sex attractive substance of the silkworm Bombyx mori. Fournal of Endocrinology 27 IX-XVI.

Butler CG 1967 Insect pheromones. Biological Reviews 42 42-87.

Byskov C, Andersen CY, Nordholm L, Thogersen H, Guoliang X, Wassmann O, Andersen JB, Guddal R \& Roed T 1995 Chemical structure of sterols that activate oocyte meiosis. Nature 374 559-562.

Chang C, Kwok SF, Bleecker AB \& Meyerowitz EM 1993 Arabidopsis ethylene-response gene ETR1: similarity of product to two-components regulators. Science $\mathbf{2 6 2}$ 539-544.

Chen Z, Silva H \& Kleissig DF 1993 Active oxygen species in the induction of plant systemic acquired resistance by salicylic acid. Science 262 1883-1886.

Chinkers M, Garbers DL, Chang MS, Lowe DG, Chin H, Goeddel DV \& Schulz S 1989 A membrane form of guanylate cyclase is an atrial natriuretic peptide receptor. Nature 338 78-83.

Cleveland LR 1959 Sex induced with ecdysone. Proceedings of the National Academy of Sciences of the USA 64 747-753.

Colasanti M, Lauro GM \& Venturini G 1995 NO in Hydra. Nature 374505.

Craik CS, Largman C, Fletcher T, Roczniak S, Barr PJ, Fletterick R \& Rutter WJ 1985 Redesigning trypsin: alteration of substrate specificity. Science 228 291-297.

Crisp DJ \& Meadows PS 1962 The chemical basis of gregariouness in cirripides. Proceedings of the Royal Society (B) 156 500-520.

Csaba G 1980 Phylogeny and ontogeny of hormone receptors: the selection theory of receptor formation and hormonal imprinting. Biological Reviews 55 47-63.

Csaba G \& Nemeth G 1980 Effect of hormones and their precursors on Protozoa. The selective responsiveness of Tetrahymena. Comparative Biochemistry and Physiology 65B 387-390.

Csaba G \& Fulop K 1987 Steroid hormone (prednisolone) influence on the unicellular Tetrahymena (an electron microscope study). Acta Protozoologica 26 233-236.

De Beer G 1954 Archaeopteryx and evolution. Advt. Science 11 $160-170$. 
De Longcamp D, Lubet P \& Dubrowsky M 1974 The 'in vitro' biosynthesis of steroids by the gonads of the mussel (Mytilus edulis). General and Comparative Endocrinology 22 116-127.

Diez A, Sancho MJ, Egana M, Trueba M, Marino A \& Maccarella JM 1984 An interaction of testosterone with cell membranes. Hormone and Metabolic Research 16 475-477.

Donta ST \& Moon HW 1974 Detection of heat-labile Escherichia coli enterotoxin with the use of adrenal cells in tissue culture. Science 183 334-336.

Drutz DJ, Huppert M, Sun SH \& McGuire WL 1981 Human sex hormones stimulate the growth and maturation of Coccidioides immitis. Infection and Immunity 32 897-907.

Dulka JG, Stacey NE, Sorensen PW \& Van der Kraak GJ 1987 A steroid sex pheromone synchronizes male-female spawning readiness in gold fish. Nature 325 251-253.

Duntze W, Mackay VL \& Manney TR 1970 Saccharomyces cerevisiae: a diffusible sex factor. Science 168 1472-1473.

Duve H \& Thorpe A 1981 Gastrin/cholecytokinin (CCK)-like immunoreactive neurones in the brain of the blowfly Calliphora erythrocephala (Diptera). General and Comparative Endocrinology 43 381-391.

Duve H, Thorpe A \& Lazarus NR 1979 Isolation of material displaying insulin-like immunological and biological activity from the brain of the blowfly, Calliphora vomitoria. Biochemical Fournal 184 221-227.

Eisenschlos CD, Paladini AA, Vedia LMY \& Torres HN 1986 Evidence for the existence of an $\mathrm{N}_{\mathrm{s}}$-type regulatory protein in Trypanosoma cruzi membranes. Biochemical fournal 237 913-917.

El Mofty MM \& Smyth JD 1964 Endocrine control of encystation in Opalina ranarum parasitic in Rana temporaria. Experimental Parasitology 15 185-199.

Escriva H, Safi R, Hanni C, Langlois MC, Saumitou-Laprade P, Stehelin D, Capron A, Pierce R \& Laudet V 1997 Ligand binding was acquired during evolution of nuclear receptors. Proceedings of the National Academy of Sciences of the USA 94 6803-6808.

Falkmer S, Elde RP, Hellerstrom C \& Peterson B 1978 Phylogenetics aspects of somatostatin in the gastroenteropancreatic (GEP) endocrine system. Metabolism 27 1193-1196.

Feldman D, Do Y, Burshell A, Stathis P \& Loose DS 1982 An estrogen-binding protein endogenous ligand in Saccharomyces cerevisiae: possible hormone-receptor system. Science 218 297-298.

Feldman D, Tokes LG, Stathis PA, Miller SC, Kurz W \& Harvey D 1984 Identification of $17 \beta$-estradiol as the estrogenic substance in Saccharomyces cerevisiae. Proceedings of the National Academy of Sciences of the USA $\mathbf{8 1}$ $4722-4726$.

Ferlund P 1974 Structure of red-pigment concentratinghormone of the shrimp Pandalus borealis. Biochimica et Biophysica Acta 371 304-311.

Firtel RA, Van Haastert PJM, Kimmel AR \& Devreotes PN 1989 G-protein linked signal transduction pathways in development: Dictyostelium as an experimental system. Cell 58 235-239.

Fisher FM Jr \& Sandborn RC 1962 Production of insect juvenile hormone by the microsporidian parasite Nosema. Nature 1941193.

Franke RR, Konig B, Sakmar TP, Khorana HG \& Hofmann KP 1990 Rhodopsin mutants that bind but fail to activate transducin. Science 250 123-125.

Gerish G 1987 Cyclic AMP and other signals controlling cell development and differentiation in Dictyostelium. Annual Review of Biochemistry 56 853-879.

Geuns JMC 1978 Steroid hormones and plant growth and development. Phytochemistry 17 1-14.
Gilbert LI \& Schneiderman HA 1958 Occurrence of substrates with juvenile hormone activity in adrenal cortex of vertebrates. Science 128844.

Gould SJ \& Vrba ES 1982 Exaptation, a missing term in the science of form. Paleobiology 8 4-15.

Grimm-Jorgensen 1983 Immunoreactive somatostatin in two pulmonate gastropods. General and Comparative Endocrinology 49 108-114.

Grosman MI 1979 Chemical messengers: a view from the gut. Federal Procurement 38 2341-2343.

Gustavson AR, Dawson ME \& Bonnet DG 1987 Androstenol, a putative human pheromone, affects human (Homo sapiens) male choice performance. Fournal of Comparative Psychology $101210-211$.

Hales CN 1985 Lysosomes and prohormone activation. Nature 31420

Hanaoka K \& Takahashi SY 1976 Effect of a hyperglycemic factor on hemolymph trealose and fat body carbohydrates in the American cockroach. Insect Biochemistry 6 621-625.

Henderson IW 1997 Endocrinology of the vertebrates. In Handbook of Physiology, vol I, section 13, pp 623-749. Ed WH Dantzler. New York and Oxford: Oxford University Press and American Physiological Society.

Highnam KC \& Hill L 1977 Endocrine mechanisms in the Insecta - I. In The Comparative Endocrinology of Invertebrates, pp 104-130. Eds EJW Barrington \& AJ Willis. London: Edward Arnold.

Hwang PK \& Fletterick RJ 1986 Convergent and divergent evolution of regulatory sites in eukaryotic phosphorylases. Nature 324 80-84.

Jackson JMD 1981 Abundance of immunoreactive thyrotropinreleasing hormone-like material in the alfalfa plant. Endocrinology 108 344-346.

Janakidevi K, Dewey VC \& Kidder GW 1966 The biosynthesis of catecholamines in two genera of protozoa. Fournal of Biological Chemistry 241 2576-2578.

Judy KJ, Schooley DA, Hall MS, Bergot BJ \& Siddall JB 1973 Chemical structure and absolute configuration of a juvenile hormone from grasshopper corpora allata in vitro. Life Sciences 13 1511-1516.

Kaback DB 1985 Hormone receptor-effector complex evolution. Nature 316490.

Kikuyama S, Toyoda F, Ohmiya Y, Matsuda K, Tanaka S \& Hayashi H 1995 Sodefrin: a female-attracting peptide pheromone in newt cloacal glands. Science 267 1643-1645.

King K, Dohlman HG, Thorner J, Caron MG \& Lefkowitz RJ 1990 Control of yeast mating signal transduction by a mammalian $\beta_{2}$-adrenergic receptor and $G_{\mathrm{s}} \alpha$ subunit. Science $250121-123$.

Kochert G 1978 Sexual pheromones in algae and fungi. Annual Review of Plant Physiology 29 461-486.

Kurosky A, Markel DE, Peterson JW \& Fitch WM 1977 Primary structure of cholera toxin $\beta$-chain: a glycoprotein hormone analog? Science 195 299-301.

Lee J, Horuk R, Rice GC, Bennett GL, Camerato T \& Wood WI 1992 Characterization of two high affinity human interleukin-8 receptors. Fournal of Biological Chemistry 267 16283-16287.

Legros F, Videnhoef P, Dumont J, Hanson B, Jeanmart J, Massant B \& Conard V 1975 Specific binding of insulin to the unicellular alga Acetabularia mediterranea. Protoplasma 86 119-137.

Leichtling BH, Coffman DS, Yearer ES \& Rickenberg HV 1981 Occurrence of the adenylate cyclase 'G-protein' in membranes of Dictyostelium discoideum. Biochemical and Biophysical Research Communications 102 1187-1195.

Lenhoff HM 1968 Behavior, hormones and Hydra. Science 161 434-442. 
Le Roith D, Shiloach J, Roth J \& Lesniak MA 1980 Evolutionary origin of vertebrate hormones: substances similar to mammalian insulins are native to unicellular eukaryotes. Proceedings of the National Academy of Sciences of the USA 77 6184-6188.

Le Roith D, Shiloach J, Roth J \& Lesniak MA $1981 a$ Insulin: a closely related molecule is native to Escherichia coli. Fournal of Biological Chemistry 256 6533-6536.

Le Roith D, Lesniak MA \& Roth J $1981 b$ Insulin in insects and annelids. Diabetes 30 70-76.

Le Roith D, Shiloach J, Berelowitz M, Frohman LA, Liotta AS, Krieger DT \& Roth J 1983 Are messenger molecules in microbes the ancestors of the vertebrate hormones and tissue factor? Federal Proceedings 42 2602-2607.

Le Roith D, Berelowitz M, Pickens W, Crosby LK \& Shiloach J $1985 a$ Somatostatin-related material in E. coli: evidence for molecular forms. Biochimica et Biophysica Acta $\mathbf{8 3 8}$ $335-340$.

Le Roith D, Pickens W, Wilson GL, Miller B, Berelowitz M, Vinik AI, Collier E \& Cleland CF $1985 b$ Somatostatin-like material is native to flowering plants. Endocrinology 117 2093-2097.

Le Roith D, Delahuney G, Wilson GL, Roberts CT Jr, Shemer J, Hart C, Lesniak MA, Shiloach J \& Roth J 1986 Evolutionary aspects of the endocrine and nervous systems. Recent Progress in Hormone Research 42 549-587.

Loose DS \& Feldman D 1982 Characterization of a unique corticosterone-binding protein in Candida albicans. Fournal of Biological Chemistry 257 4925-4930.

Loose DS, Schurman DJ \& Feldman D 1981 A corticosterone binding protein and endogenous ligand in C. albicans indicating a possible steroid-receptor system. Nature 293 $477-479$.

Loose DS, Price-Stover E, Restrepo A, Stevens DA \& Feldman 1983 Estradiol binds to a receptor-like cytosol binding protein and initiates a biological response in Paracoccidioides brasiliensis. Proceedings of the National Academy of Sciences of the USA $807659-7663$.

Loumaye E, Thorner J \& Catt KJ 1982 Yeast mating pheromone activates mammalian gonadotrophs: evolutionary conservation of a reproductive hormone? Science $\mathbf{2 1 8}$ $1323-1325$.

Macchia U, Bates RW \& Pastan I 1967 Purification and properties of a thyroid-stimulating factor isolated from Clostridium perfringens. Fournal of Biological Chemistry 242 3726-3730.

Machlis L, Nutting WH \& Rapoport H 1968 The structure of sirenin. Fournal of the American Chemical Society 90 1674-1676.

Mackman RS \& Sutherland EQ 1965 Adenosine 3',5'phosphate in Escherichia coli. Fournal of Biological Chemistry 240 1309-1311.

McMorris TC, Seshasdri R, Wrihe GR, Aresenault GR \& Barksdale AW 1975 Structures of oogoniol-1, -2 and -3, steroid sex hormones of the water mold Achlya. Fournal of the American Chemical Society 97 2544-2545.

Manaranche R \& L'Hermite P 1973 Etude des amines biogenes de Glycera convoluta K (Annelid Polychete). Zeitschrift für Zelforschung 137 21-36.

Maruo T, Cohen H, Segal SJ \& Koide SS 1979 Production of choriogonadotropin-like factor by a microorganism. Proceedings of the National Academy of Sciences of the USA 76 6622-6626.

Mason RT, Fales HM, Jones TH, Pannell LK, Chinn JW \& Crews D 1989 Sex pheromones in snakes. Science $\mathbf{2 4 5}$ 290-293.

Matsumara K 1995 Tetrodotoxin as a pheromone. Nature $\mathbf{3 7 8}$ $563-564$
Melrose DR, Reed HCB \& Patterson RLS 1971 Androgen steroids associated with boar odour as an aid to the detection of oestrus in pig artificial insemination. British Veterinary fournal 107 497-501.

Meselson MS \& Radding CM 1975 A general model for genetic recombination. Proceedings of the National Academy of Sciences of the USA 72 358-361.

Monsma FJ, McVittie LD, Gerfen CR, Mahan LC \& Sibley DR 1989 Multiple $\mathrm{D}_{2}$ dopamine receptors produced by alternative RNA splicing. Nature 342 926-929.

Mordue W \& Stone JV 1976 Comparison of the biological activities of an insect and a crustacean neurohormone that are structurally similar. Nature 264 287-289.

Mordue W \& Stone JV 1977 Relative potencies of locust adipokinetic hormone and prawn red pigment concentrating hormone in insect and crustacean systems. General and Comparative Endocrinology 33 103-108.

Morley JE, Meyer N, Pekary AE, Melmed, Carlso HE, Briggs JE \& Herskam JM 1980 A prolactin inhibitory factor with immunocharacteristics similar to thyrotropin releasing factor $(\mathrm{TRH})$ is present in rat pituitary tumors $(\mathrm{GH} 3$ and W5), testicular tissue and a plant material, alfalfa.

Biochemical and Biophysical Research Communications 96 $47-53$.

Muggeo M, Ginsberg BH, Roth J, Neville DM Jr, Demeyts P \& Kahn CR 1979 The insulin receptor in vertebrates is functionally more conserved during evolution than insulin itself. Endocrinology 104 1393-1402.

Muller DG \& Jaenicke L 1973 Fucoserraten, the female sex attractant of Fucus serratus L. FEBS Letters 30 137-139.

Muller DG, Jaenicke L, Donike M \& Akintobi T 1971 Sex attractant in brown algae: chemical structure. Science $\mathbf{1 7 1}$ $815-817$.

Namba T, Sugimoto Y, Negishi M, Irie A, Ushikubi F, Kakizuka A, Ito S, Ichikawa A \& Narumiya S 1983 Alternative splicing of $\mathrm{C}$-terminal tail of prostaglandin $\mathrm{E}$ receptor subtype EP3 determines G-protein specificity. Nature 306 32-36.

Nes W \& McKean ML 1977 Biochemistry of Steroids and other Isopentenoids. Baltimore: University Park Press.

Niall HD 1982 The evolution of peptide hormones. Annual Review of Physiology 44 615-624.

O’Malley BW 1989 Editorial: Did eukaryotic steroid receptors evolve from intracrine gene regulators? Endocrinology 125 1119-1120.

Paech K, Webb P, Kuiper GGJM, Nilsson S, Gustafsson JA, Kushner PJ \& Scanian TS 1997 Differential ligand activation of estrogen ER $\alpha$ and ER $\beta$ at AP1 sites. Science 277 1508-1510.

Pfeffer S \& Ullrich A 1985 Epidermal growth factor: is the precursor a receptor? Nature 313184.

Plisetskaya E, Kazarov VK, Slititskaya L \& Leibson LG 1978 Insulin producing cells in the gut of freshwater bivalve molluscs Anodonta cygnea and Unio pyctorum and the role of insulin in the regulation of their carbohydrate metabolism. General and Comparative Endocrinology 35 133-145.

Pullen RA, Lindsay DG, Wood SP, Tickle IJ, Blundell TL, Wollmer A, Krail G, Brandenburg D, Zahn H, Glemann J \& Gammeltoft S 1976 Receptor-binding region of insulin. Nature 259 369-373.

Rao CV \& Chegini N 1983 Nuclear receptors for gonadotropins and prostaglandins. In Evolution of Hormone Receptor Systems, pp 413-423. New York: AR Liss.

Richert ND \& Ryan RJ 1977 Specific gonadotropin binding to Pseudomonas maltophilia. Proceedings of the National Academy of Sciences of the USA 74 878-882.

Riedel H, Dull TJ, Schlessinger J \& Ullrich A 1986 A chimaeric receptor allows insulin to stimulate tyrosine kinase 
activity of epidermal growth factor receptor. Nature 324 68-70.

Rosenzweig JL, Havrankova J, Lesniak MA, Brownstein M \& Roth J 1980 Insulin is ubiquitous in extrapancreatic tissues of rat and humans. Proceedings of the National Academy of Sciences of the USA 77 572-576.

Saden-Krekula M, Tajic M \& Kolbah D 1971 Testosterone, epitestosterone and androstenedione in the pollen of Scots pine P. silvestris. Experientia 27 108-109.

Saxe CL, Johnson RL, Devreotes PN \& Kimmel AR 1991 Expression of cAMP receptor-gene of Dictyostelium and evidence for a multigene family. Genes and Development $\mathbf{5}$ $1-8$.

Schapp P 1984 cAMP pulses coordinate morphogenetic movement during fruiting body formation of Dictyostelium minutum. Proceedings of the National Academy of Sciences of the USA 81 2122-2126.

Schar G, Price-Stover E, Clemons KV, Feldman D \& Stevens DA 1986 Progesterone binding and inhibition of growth in Trichophyton mentagrophytes. Infection and Immunity $\mathbf{5 2}$ 763-767.

Schildknecht H, Siewerdt R \& Maschwitz 1966 A vertebrate hormone as defensive substance of the water beetle Dytiscus marginalis. Angewandte Chemie International Edition (English) $\mathbf{5} 421$.

Schildknecht H, Birringer H \& Maschwitz U 1967 Testosterone as protective agent of the water beetle Ilybius. Angewandte Chemie International Edition (English) 6558.

Schimz A, Hinsh KD \& Hildebrand E 1989 Enzymatic and immunological detection of a G-protein in Halobacterium halobium. FEBS Letters 249 59-61.

Schwabe C, Le Roith D, Thompson RP, Shiloach J \& Roth J 1983 Relaxin extracted from protozoa (Tetrahymena pyriformis): molecular and immunologic properties. Fournal of Biological Chemistry 258 2778-2781.

Schwemmler W 1984 Evolution of the precytes. In Reconstruction of Cell Evolution: a Periodic System, pp 45-89. Ed W Schwemmler. Florida: CRC Press.

Shemshedini L \& Wilson TG 1990 Resistance to juvenile hormone and an insect growth regulator in Drosophila is associated with an altered cytosolic juvenile hormone binding protein. Proceedings of the National Academy of Sciences of the USA 87 2072-2076.

Shimomura O, Suthers HLB \& Bonner JT 1982 Chemical identity of the acrasin of the cellular slime mold Polysphondilium violaceum. Proceedings of the National Academy of Sciences of the USA 79 7380-7384.

Slama K \& Williams CM 1965 Juvenile hormone activity for the bug Pyrrochoris apterus. Proceedings of the National Academy of Sciences of the USA 54 411-414.

Starr RC \& Jaenicke L 1974 Purification and characterization of the hormone initiating sexual morphogenesis in Volvox carteri f. magariensis. Proceedings of the National Academy of Sciences of the USA 71 1050-1054.

Stoka AM 1987 Ecdysteroids, juvenile hormones and metamorphosis in Triatominae. In Chagas' Disease Vectors, vol III, pp 71-99. Eds RR Brenner \& AM Stoka. Florida: CRC Press.

Stoka AM 1996 Activity of juvenile hormone and juvenile hormone analogues on the growth of Trypanosoma cruzi. Fournal of Steroid Biochemistry and Molecular Biology 59 495-500.

Stoka AM, Ronderos JR \& Reboredo GR $1987 a$ Insect control by endocrine disorder. In Chagas' Disease Vectors, vol III, pp 139-147. Eds RR Brenner \& AM Stoka. Florida: CRC Press.

Stoka AM, Salomon OD \& Noriega FG $1987 b$ Physiology of Triatominae's reproduction. In Chagas' Disease Vectors, vol II, pp 109-129. Eds RR Brenner \& AM Stoka. Florida: CRC Press.

Stoka AM, Rivas C, Segura EL, Rodriguez JB \& Gros EG 1990 Biological activity of synthetic juvenile hormone analogues (JHA) for Trypanosoma cruzi. Zeitschrift für Naturforschung 45b 96-98.

Stone JV, Mordue W, Batley KE \& Morris HR 1976 Structure of locust adipokinetic hormone, a neurohormone that regulates lipid utilization during flight. Nature 263 207-211.

Sturaro A, Guerriero A, Declauser R \& Pietra F 1982 A new unexpected marine source of a moulting hormone; isolation of ecdysterone in large amounts from the zooxanthid Gerardia savaglia. Experientia 38 1184-1185.

Tainer JA, Getzoff ED, Alexander H, Houghten RA, Olson AJ \& Lerner RA 1984 The reactivity of anti-peptide antibodies is a function of the atomic mobility of sites in a protein. Nature 312 127-134.

Tata JR 1964 Basal metabolic rate and thyroid hormones. Advances in Metabolic Disorders 1 153-189.

Thambi NC, Quan F, Wolfgang WJ, Spiegel A \& Forte M 1989 Immunological and molecular characterization of $\mathrm{G}_{\mathrm{o}}$-like proteins in the Drosophila central nervous system. Fournal of Biological Chemistry 264 18552-18560.

Toms RB 1984 Environmental selective pressure and the origin of insect metamorphosis. Fournal of the Entomological Society of South Africa 47 269-276.

Vallesi A, Giuli G, Bradshaw RA \& Luporini P 1995 Autocrine mitogenic activity of pheromones produced by the protozoan ciliate Euplotes raikovi. Nature 376 522-524.

Van Haastert PJM, De Wit RJW, Grijma Y \& Konijn TM 1982 Identification of a pterin as the acrasin of the cellular slime mold Dictyostelium lacteum. Proceedings of the National Academy of Sciences of the USA 79 6270-6274.

Vladusic EA, Bussmann LE, Visconti PE, Stoka AM, Rodriguez JB, Gros EG \& Charreau EH 1994 Effects of juvenile hormone on mammalian steroidogenesis. Fournal of Steroid Biochemistry and Molecular Biology $\mathbf{5 0}$ 181-187.

Watanabe M \& Po L 1976 Membrane bound 3 $\beta$ - and $17 \beta$-hydroxysteroid dehydrogenase and its role in steroid transport in membrane vesicles of Pseudomonas testosteroni. Fournal of Steroid Biochemistry 7 171-175.

Watanabe M, Phillips K \& Chen T 1973a Steroid receptor in Pseudomonas testosteroni released by osmotic shock. Fournal of Steroid Biochemistry 4 613-622.

Watanabe M, Phillips K \& Watanabe H $1973 b$ Induction of steroid-binding activity in Pseudomonas testosteroni. Fournal of Steroid Biochemistry 4 623-632.

Weber IT, Takio K, Titani K \& Steitz M 1982 The cAMP-binding domains of the regulatory subunit of cAMP-dependent protein-kinase and the catabolite gene activator are homologous. Proceedings of the National Academy of Sciences of the USA 79 7679-7683.

Wedemayer GJ, Patten PA, Wang LH, Schultz PG \& Stevens KC 1997 Structural insights into the evolution of an antibody combining site. Science 276 1665-1669.

Weinberger C, Thompson CL, Ong ES, Lebo R, Gruol DJ \& Evans RM 1986 The c-erb-A gene encodes a thyroid hormone receptor. Nature 324 641-646.

Weiss M, Ingbar SH, Winblad S \& Kasper DL 1983 Demonstration of a saturable binding site for thyrotropin in Yersinia enterocolitica. Science 219 1331-1333.

Welsh JH \& King EC 1970 Catecholamines in planarians. Comparative Biochemistry and Physiology 36 683-688.

White BA \& Nicoll CS 1979 Prolactin receptors in Rana catesbeiana during development and metamorphosis. Science 204 851-853. 
Whiteway M, Hougan L, Dignard D, Thomas DI, Bell L, Saari GC, Grant FJ, O'Hara P \& MacKay VL 1989 The STE4 and STE18 gene of yeast encode potential $\beta$ and $\gamma$ subunits of the mating factor receptor-coupled $G$-protein. Cell 56 467-477.

Wilkinson LE \& Pringle JR 1974 Transient G1 arrest of $S$. cerevisiae of mating type $\alpha$ by a factor produced by cells of mating type a. Experimental Cell Research 89 175-187.

Williams CM, Morhead LV \& Pulis JF 1959 Juvenile hormone in thymus, human placenta and other mammalian organs. Nature 183405.

Wilson AG, Carlson SS \& White TJ 1977 Biochemical evolution. Annual Review of Biochemistry 46 573-639.
Yang NN, Venugopalan M, Hardikar S \& Glasebrook A 1996 Identification of an estrogen response element activated by metabolites of $17 \beta$-estradiol and raloxifene. Science 273 1222-1225.

Zimmerman EG 1979 Peptides of the brain and gut: introductory remarks. Federal Proceedings $\mathbf{3 8}$ 2286-2287.

Zioudrov C, Streaty RA \& Klee WA 1979 Opioid peptides derived from food proteins. The exorphins. Fournal of Biological Chemistry 254 2446-2450.

REVISED MANUSCRIPT RECEIVED 17 August 1998 
